\title{
FOCO DE CHUVA
}

\section{Adriana Zapparoli ${ }^{1}$}

\footnotetext{
${ }^{1}$ Adriana Zapparoli (Campinas - São Paulo) é escritora e tradutora. Realizou pós-doutoramento pela Universidade Estadual de Campinas (S.P). Publicou os livros de poesia A Flor da Abissínia (versão bilíngüe) em 2007; Cocatriz em 2008; Violeta de Sofia em 2009; Tílias e Tulipas (versão bilíngüe) em 2010; O Leão de Neméia em 2011; Flor de Lírio (versão bilingue) em 2012, Flor de Lótus em 2013, a tradução poética para Mosaico Fluido em 2014 todos trabalhos editados pela Lumme Editor (Bauru - S.P). Em 2012 publicou a plaquete poética Lontra Corola Libido editada pelo Centro Cultural São Paulo.
} 


\title{
CENA 1
}

Centrado em ambiência em luz de foco de penumbra noturna, em diálogo, dialogando com o livro em cima móvel. Uma bacia no chão. Há chuva.

\author{
Luz, Música e Silêncio:
}

\section{Homem:}

- há uma lasca de perfume de chuva. enquanto remexo as folhas dentro da bacia, veja! há uma almofada vazia no lixo da chuva.

\section{Livro:}

- são costuras entre as finuras da obra na chuva. são ascos em bacias...

\section{Homem:}

- é que tudo ao redor vem dessa síndrome de chuva. do solado desse sapato. Desse cheiro impregnado de vulva.

- hoje, encontrei as bordas dos alinhavos em um buraco da bacia, alterando os contornos, são tapuias?

\section{Livro:}

- não. É sua língua um homônimo de tupi cabocla veja a textura é o resto da rotina côncava e os seus hormônios. 
Pausa, Música e Silêncio:

\section{Homem}

- minhas botinas são costuradas em linha de chuva.

- minhas unhas usurpam a lástima desse encalço.

- esmago o dia com dois dedos em bebida e aspirina, ou um beijo de cocaína.

\section{Livro:}

- quando eu alço voo e flutua seu passado de chuva; sapateio pelo buraco das fissuras de onde urram outras comissuras.

\section{Pausa, Música e Silêncio:}

\section{Homem:}

- as rachaduras vão penetrando o buraco aberto no sapato até a linha da cintura.

- ali pendula o escroto em araras miniaturas até esse pescoço.

- veja são cabelos tipo gotas em uma boina em pingo de chuva.

- essa permuta comunga suas narinas.

\section{Livro:}

- e, ainda, se dentro é livro se não literatura, se não poesia, estamos afogados em tecido de chita...

- para que a vida cumpra a lasca da chuva de perfume da bacia.

\section{Silêncio e Escuro.}

